\title{
Characterization and Distribution of a Potyvirus Associated with Passion Fruit Woodiness Disease in Uganda
}

\begin{abstract}
M. Ochwo-Ssemakula, Department of Agricultural Production, Makerere University, P.O. Box 7062, Kampala, Uganda; T. Sengooba, International Food Policy Research Institute, P.O. Box 28565, Kampala, Uganda; J. J. Hakiza, National Agricultural Research Laboratories, Kampala, Uganda; E. Adipala, Regional Universities Forum for Capacity Building in Agriculture, P.O. Box 7062, Kampala, Uganda; R. Edema, Department of Crop Science, Makerere University, Kampala, Uganda; M. G. Redinbaugh, USDA, ARS Corn and Soybean Research Unit, and Department of Plant Pathology, The Ohio State University, OARDC, 1680 Madison Avenue, Wooster, OH 44691, USA; V. Aritua, National Agricultural Biotechnology Centre, National Agricultural Research Laboratories, P.O. Box 7065, Kampala, Uganda, and Department of Plant Pathology, Kansas State University, 4024 Throckmorton Plant Sciences Center, Manhattan, KS 66506, USA; and S. Winter, Plant Virus Department, Deutsche Sammlung von Mikroorganismen und Zellkulturen GmbH, Messeweg 11/12, Braunschweig 38104, Germany
\end{abstract}

\begin{abstract}
Ochwo-Ssemakula, M., Sengooba, T., Hakiza, J. J., Adipala, E., Edema, R., Redinbaugh, M. G., Aritua, V., and Winter, S. 2012. Characterization and distribution of a Potyvirus associated with passion fruit woodiness disease in Uganda. Plant Dis. 96:659-665.

This article describes the incidence and etiology of a viral disease of passion fruit in Uganda. Symptoms, including those characteristic of passion fruit woodiness disease (PWD), were observed on $32 \%$ of plants in producing areas. Electron microscopic observations of infected tissues revealed flexuous filaments of ca. $780 \mathrm{~nm}$. Enzymelinked immunosorbent assays indicated a serological relationship with Cowpea aphid-borne mosaic virus (CABMV) and Passion fruit ringspot virus (PFRSV). In host range studies, only species in the families Solanaceae and Chenopodiaceae were susceptible, and neither Vigna unguiculata nor Phaseolus vulgaris became infected. Coat protein (CP) gene sequences of eight isolates exhibited features typical of potyviruses and were highly similar ( 88 to $100 \%$ identity). However,

the sequences had limited sequence identity with CP genes of two of the three potyviruses reported to cause PWD: East Asian Passiflora virus and Passion fruit woodiness virus (PWV). Deduced amino acid sequences for the $\mathrm{CP}$ of isolates from Uganda had highest identity with Bean common mosaic necrosis virus (BCMNV) (72 to 79\%, with evolutionary divergence values between 0.17 and 0.19 ) and CABMV ( 73 to $76 \%$, with divergence values between 0.21 and 0.25 ). Based on these results and in accordance with International Committee for Taxonomy of Viruses criteria for species demarcation in the family Potyviridae, we conclude that a previously unreported virus causes viral diseases on passion fruit in Uganda. The name "Ugandan Passiflora virus" is proposed for this virus.
\end{abstract}

Commercial production of passion fruit in Uganda began around 1960, following its introduction from Kenya (25). Shortly afterward, the newly established large plantations were devastated several times by pests and infectious diseases. As a result, several large farming enterprises were either abandoned or downsized in favor of small and isolated plantings that could be better protected, resulting in the subsistence level of production (26) that is still prevalent in Uganda today (36). In the late 1980s, the Government of Uganda initiated an export diversification program that targeted horticultural crops, including passion fruit, as a means of boosting national revenue (16). Dominance of the passion fruit production chain by small-scale farmers (36) enhanced the potential of this crop to affect the socio-economics of rural development (27). Clones of a new variety, the Kawanda Hybrid, which had just been released by the National Agricultural Research Organisation of Uganda (NARO), were introduced. This cultivar had high levels of disease resistance as well as superior agronomic traits compared to other cultivars in the East African region, and thus gave Uganda a competitive advantage for the European market (8). Thus, several commercial ventures were established and export trade began (39).

Corresponding author: M. Ochwo-Ssemakula,

E-mail: mknossemakula@agric.mak.ac.ug

* The $\boldsymbol{e}$-Xtra logo stands for "electronic extra" and indicates that Figure 1 appears in color in the online edition.

Accepted for publication 15 September 2011.

http://dx.doi.org/10.1094/PDIS-03-11-0263

(C) 2012 The American Phytopathological Society
Shortly after commercial production started, pilot field studies revealed extensive symptoms indicative of several fungal and virus-like diseases characterized by foliar mosaics, vein clearing, fruit hardening, and malformation $(15,19)$. Up to $90 \%$ of passion fruit fields in areas of central Uganda had plants with symptoms characteristic of virus infection (2), and almost 50\% marketable yield loss was recorded (28). The losses attributed to viral diseases have continued to increase and remain a challenge to passion fruit production (36). The situation is further compounded by limited knowledge on the identity of the causal viral agent(s), extent of infection, and associated damage levels in the various regions of Uganda. This paucity of information has rendered it impossible to develop an effective disease management strategy. A number of control measures, such as use of disease-free planting material, were attempted but without much success (3).

The characteristic hardening and malformation of fruits found on virus-infected plants have been related to the passion fruit woodiness disease (PWD) attributed elsewhere to several viruses belonging to the genus Potyvirus, including Passion fruit woodiness virus (PWV) (34) and relatives of Cowpea aphid-borne mosaic virus (CABMV) $(9,24)$. More recently, the East Asian Passiflora virus (EAPV) has been confirmed to cause a similar disease in Japan (22). In this study, we present results of intensive surveys in Uganda for viruses known to infect passion fruit worldwide. Biological and molecular techniques were also used to characterize a potyvirus previously reported to cause leaf mottling and distortion and fruit woodiness in this horticultural crop in Uganda (29). The findings of this research are considered important for a better understanding of the viral disease situation on passion fruit in Uganda and for the development of effective disease management strategies. 


\section{Materials and Methods}

Surveys and sample collection. In 2003, 2005, and 2007, surveys were conducted in 15 main passion fruit growing districts covering the four major agro-ecological regions of Uganda (38). A total of 77 farms, and three wild collections, were randomly selected and scored for the presence of virus symptoms. Because most of the farmers' fields were relatively small, the incidence of virus-like symptoms in each field was visually assessed on every plant and recorded as a percentage of total plants. For symptom severity, the scale 1 to 5 developed for assessing cassava mosaic disease severity (35) was adopted, where 1 indicated absence of visible viral symptoms and 5 was used for more than $75 \%$ symptom coverage on infected leaves. Where virus-like symptoms were found, leaves, scions, and medium-wood cuttings were collected for analysis. A total of 164 such samples were collected from farmers' fields and wild plants. Additional samples were obtained from experimental plots at the National Agricultural Research Laboratories, Uganda. Three virus isolates maintained at the German Collection of Microorganisms and Cell Cultures (DSMZ) were used as reference materials. These included: isolate PV-0707, obtained from a passion fruit from Wakiso district in Uganda (GenBank, under accession number FR694183); isolate PV-0292, a strain of

Table 1. Capsid protein amino acid sequences obtained from GenBank and used for comparative analysis

\begin{tabular}{|c|c|c|c|}
\hline Virus isolate & Host of origin & $\begin{array}{l}\text { Country } \\
\text { of origin }\end{array}$ & $\begin{array}{l}\text { Accession } \\
\text { number }\end{array}$ \\
\hline BCMV-NL1 & - & - & AAB28498 \\
\hline BCMV-Y & Cowpea & China & AJ312438 \\
\hline BCMNV-Durango & - & Mexico & AAK06834 \\
\hline BCMNV-TN1 & - & - & AAA 80270 \\
\hline CABMV- F-144 & Passion fruit & Brazil & AAR89898 \\
\hline CABMV-BA-Itb & Passion fruit & Brazil & ABD62096 \\
\hline CABMV-BA-Jgr & Passion fruit & Brazil & ABD62095 \\
\hline CABMV-DF-Brs & Passion fruit & Brazil & ABD62100 \\
\hline CABMV-ES-Vni & Passion fruit & Brazil & ABD62097 \\
\hline CABMV-F-101 & Passion fruit & Brazil & AAR08936 \\
\hline CABMV-GA & Sesame & USA & U90326 \\
\hline CABMV-Ib & Cowpea & Ivory Coast & AJ132414 \\
\hline CABMV-M2 & Curcubit & Brazil & AAR08937 \\
\hline CABMV-M3 & Curcubit & Brazil & AAS60103 \\
\hline CABMV-MG-Avr & Passion fruit & Brazil & ABD62093 \\
\hline CABMV-PB2 & Passion fruit & Brazil & AAP04520 \\
\hline CABMV-PE2 & Passion fruit & Brazil & AAP04516 \\
\hline CABMV-PE3 & Passion fruit & Brazil & AAP04518 \\
\hline CABMV-PE4 & Passion fruit & Brazil & AAP04519 \\
\hline CABMV-PE-Bnt & Passion fruit & Brazil & ABD62094 \\
\hline CABMV-SAP- $1^{\mathrm{a}}$ & Passion fruit & South Africa & D10053 \\
\hline CABMV-SAP-2 ${ }^{\mathrm{a}}$ & Passion fruit & South Africa & S51666 \\
\hline $\begin{array}{l}\text { CABMV-SAP- } \\
\text { Kenya }^{\text {a }}\end{array}$ & Passion fruit & Kenya & ABQ95508 \\
\hline CABMV-SE1 & Passion fruit & Brazil & AAP04521 \\
\hline CABMV-SP & Passion fruit & Brazil & AAR08935 \\
\hline CABMV-SP-Prp & Passion fruit & Brazil & ABD62099 \\
\hline CABMV-SP-Vcz & Passion fruit & Brazil & ABD62098 \\
\hline CABMV-Z & Cowpea & Zimbabwe & NC_004013 \\
\hline EAPV-AO & Passion fruit & Japan & D85849 \\
\hline EAPV-IB & Passion fruit & Japan & AB185021 \\
\hline EAPV-Taiwana & Passion fruit & Taiwan & AF208662 \\
\hline PaChV-Coaraze1 & Arabian pea & France & EU334546 \\
\hline PaChV-Coaraze2 & Arabian pea & France & EU334547 \\
\hline PVY-NTN & - & Brazil & AY840082 \\
\hline PWV-Car-1 & $\begin{array}{l}\text { Stinking } \\
\text { passionflower }\end{array}$ & Australia & ABK51619 \\
\hline PWV-CoP-1 & $\begin{array}{l}\text { Blue passion } \\
\text { flower }\end{array}$ & Australia & ABK51621 \\
\hline PWV-Culnes (CL1) & Passion fruit & Australia & AAB81114 \\
\hline PWV-Gld-1 & Passion fruit & Australia & ABK51618 \\
\hline PWV-Ku-1 & $\begin{array}{l}\text { Stinking } \\
\text { passionflower }\end{array}$ & Australia & ABK51620 \\
\hline PWV-NSW-1 & Passion fruit & Australia & AAB81115 \\
\hline
\end{tabular}

${ }^{a}$ Arbitrary isolate names assigned.
EAPV obtained from an unknown passion fruit source in Taiwan (GenBank, under accession number FR694184); and PV-0598, a virus that was isolated from Passiflora "incence" in Germany (GenBank, under accession number FR694185) and is related to the Passiflora chlorosis virus (PaChV) reported in Florida (5).

Enzyme-linked immunosorbent assays (ELISA). Serological analysis was initially carried out by antigen coated plate (ACP)ELISA with the P-3-3H8 monoclonal antibody (MAb) [DSMZ AS0573/1] (31). Further testing followed using polyclonal antibodies against three Potyvirus species, CABMV, Passion fruit ringspot virus (PFRSV), and Sri-Lankan passion fruit mottle virus (SLPMoV), and seven non-Potyvirus species, Cucumber mosaic virus (CMV), Maracuja mosaic virus (MarMV), Passion fruit yellow mosaic virus (PFYMV), Passion flower little leaf mosaic virus (PLLMV), Passiflora latent virus (PLV), Tomato ringspot virus (ToRSV), and Okra mosaic virus (OkMV). The double antibody sandwich (DAS)-ELISA was used for detection of CABMV, CMV, MarMV, OkMV, PFYMV, PFRSV, PLV, SLPMoV, and ToRSV; and triple antibody sandwich (TAS)-ELISA for detection of PLLMV. In addition to samples collected during this study, the passion fruit virus isolates PV-0292 and PV-0707 from the DSMZ plant virus collection were included in the analyses. Positive threshold values were set at twice the average value of the negative control (4).

Experimental host range assays. The partial host ranges of four virus isolates, UGM-19a (P. edulis f. edulis, Mukono district, central Uganda), UGM-58 ( $P$. edulis f. edulis $\times P$. edulis f. flavicarpa, Mbarara district, western Uganda), and EAPV PV-0292 and PV-0707, were determined by mechanical inoculation of tissue extracts to 16 herbaceous plant species, namely Nicotiana benthamiana, $N$. clevelandii, $N$. tabacum 'Xanthi', N. rustica, $N$. debneyi, $N$. hesperes, $N$. glutinosa 24A, $N$. glutinosa, $N$. occidentalis subsp. obliqua, $N$. occidentalis $\mathrm{P} 1$, Chenopodium quinoa, C. murale, $C$. foliosum, Solanum lycopersicum 'Rutgers', Datura stramonium, D. metel, Solanum melongena, Phaseolus vulgaris 'Black Turtle Soup', and four lines of the Nigerian cowpea (Vigna unguiculata), TVn 3629, TVn 4557, It 82E-10, and TVn 196.

Plants were grown in a sterilized Floradur-sand mixture $(1: 1$, wt/vol) (Floragard Vertriebs GmbH, Oldenburg, Germany) and kept in an insect-free greenhouse at 20 to $25^{\circ} \mathrm{C}$ under a 12 to $16 \mathrm{~h}$ photoperiod and evaluated for local and systemic infections for up to 30 days postinoculation. Serological analysis using MAb P-3$3 \mathrm{H} 8$ and electron microscopic observations were performed on all inoculated plants and controls.

Electron microscopy. Fresh leaf extracts were prepared by macerating approximately $0.5-\mathrm{cm}$ leaf discs in $0.1 \mathrm{M}$ sodium phosphate buffer $\left(\mathrm{Na}_{2} \mathrm{HPO}_{4} / \mathrm{NaH}_{2} \mathrm{PO}_{4}\right), \mathrm{pH}$, containing $2 \%$ PVP (wt/vol) and $0.2 \% \mathrm{Na}_{2} \mathrm{SO}_{3}$ (wt/vol). Droplets of extracts were placed on Parafilm and carbon-stabilized copper grids incubated on them for $5 \mathrm{~min}$. The grids were then washed with distilled water, negatively stained in $1 \%$ uranyl acetate $(\mathrm{pH} 4.3)$, and examined using a Zeiss EM 906 transmission electron microscope (Digivision, SIS, Muenster, Germany) at $80 \mathrm{KV}$.

Mean virus particle lengths were determined for isolates PV0707 and UGM-58 from fresh leaf extracts in immunosorbent electron microscopy (ISEM) using the procedure described by de Silva et al. (13) and an antiserum against PFRSV. Both virus isolates exhibited a serological relationship with PFRSV in ELISA. Lengths of about 100 particles were measured at a magnification of $\times 50,000$ in a Zeiss EM 906 transmission electron microscope with an online attached image analyzing system for histogram production and normal length calculation.

Sequence analysis. The passion fruit virus isolates, UGM-17 ( $P$. edulis f. edulis, Mbale district, Eastern Uganda), UGM-19a, UGM58, UGM-73 (P. edulis f. edulis $\times$ P. edulis f. flavicarpa, Masaka district, South-Central Uganda), UGM-64, UGM-67, UGM-69c ( $P$. edulis f. edulis $\times$ P. edulis f. flavicarpa, Mbarara district, SouthCentral Uganda), and PV-0707 were subjected to molecular analysis. The isolates were obtained from their original hosts that had been maintained in an insect-free screen house at the National 
Agricultural Research Laboratories, Uganda, or at the DSMZ Plant Virus Department, Germany. These eight virus isolates were positive in ELISA with antiserum for the genus Potyvirus and mostly exhibited a serological relationship to PFRSV. Total nucleic acids were extracted using the Tri Reagent method (Sigma-Aldrich), and reverse transcription-polymerase chain reaction (RT-PCR) was subsequently done using the SuperScript One-step RT kit (Invitrogen). Following a general approach to detect potyviruses, the $3^{\prime}$ terminal sequences of the viral genomes were amplified in two separate RT-PCR reactions. An oligo (dT) combined with a primer designed from the conserved WCIE/DNGTS motif in the coat protein $(\mathrm{CP})$ core region (12) or a generic primer based on the conserved aa sequence GNNSGQP in the Nuclear inclusion B (NIb) coding region of members of the family Potyviridae (10) were used to generate PCR fragments from the potyvirus template cDNA. Following purification from agarose gels, PCR products were either directly sequenced or ligated into pDrive U/A (Qiagen) or pGEM-T Easy (Promega, USA) cloning vectors following the manufacturers' protocols and subsequently electroporated into Escherichia coli DH5 $\alpha$ cells. Recombinant cDNA clones were then selected and sequenced using T7/SP6 flanking vector primers or primers derived from internal sequences. Bi-directional sequencing was done at SequiServe GmbH (Vaterstetten, Germany) or the Ohio State University, Plant-Microbe Genomics Facility (Columbus, OH).

Phylogenetic analysis. Nucleotide sequences of the CP coding region were compared to related sequences available from GenBank (Table 1) that were selected using a basic local alignment search tool (BLAST) search for related sequences using the sequences of the $3^{\prime}$ regions generated in this study. About 30 sequences, comprising available passion fruit infecting potyviruses, were included in the analyses. Multiple sequence alignments were obtained using Clustal W (37) in the BioEdit Sequence Alignment Editor package (version 7.0.4.1; Hall, 1999). To construct phylogenetic trees, genetic distances were calculated using the neighbor joining method (Poisson model) of Saitou and Nei (32). The statistical significance of branching was determined using bootstrap analyses of 1,000 different alignments from the original dataset (18) and reported as percentages. Rooted trees were plotted and visualized using the Molecular Evolutionary Genetics Analysis software (MEGA version 4; Tamura, Dudley, Nei, and Kumar 2007) with the sequence of Potato virus $Y$ (PVY) as an out-group. Sequence identities were calculated using the BioEdit Sequence Alignment Editor package (version 7.0.4.1; Hall, 1999) and CLC Protein Workbench (version 5.4; CLC bio A/S, Denmark). Evolutionary divergences were estimated using MEGA (version 4; Tamura, Dudley, Nei, and Kumar 2007).

\section{Results}

Virus survey. Field collections were conducted in four major agro-ecological zones of Uganda, where passion fruit is grown under rainfed conditions with varying environmental conditions and agronomic practices. In all areas surveyed, virus-like symptoms were prevalent in the crop. The overall average incidence of plants with conspicuous virus-like symptoms was $32 \%$ and varied among fields and regions; the highest being up to $100 \%$ in the central region and parts on the western region and lowest 0 to $5 \%$ in the eastern region, where symptomatic plants were rarely found (Table 2). The most common symptoms included leaf mosaic, mottling and diffuse chlorosis, crinkle, vein clearing and distortion, and fruit woodiness and malformation in all possible expressions and combinations (Fig. 1). In ACP-ELISA using AS-0573/1, 62 out of 164 symptomatic samples were positive for presence of potyviruses. Further testing with specific antibodies showed that these viruses were serologically related to CABMV and PFRSV, with $22 \%(36 / 164)$ reacting with each antiserum alone and 6\% (10/164) reacting with both antisera. None of the 164 samples tested positive for CMV, PFYMV, PLLMV, PLV, OkMV, MarMV, SLPMoV, and ToRSV (Table 2).

Host range. The passion fruit virus isolates PV-0707, UGM19a, and UGM-58 from Uganda only infected 10 out of the 16 plant species tested from the Solanaceae and Chenopodiaceae (Table 3). The Leguminosae, P. vulgaris, and V. unguiculata did not become infected upon inoculation. The three isolates showed variability in host range; UGM-19a had the widest host range, infecting 8 species, while PV-0707 and UGM-58 infected 7 and 5 test plant species, respectively (Table 3 ). The EAPV reference isolate from Taiwan, PV-0292, in addition to a number of plant species also systemically infected Vigna unguiculata.

Local lesions were observed on Chenopodium species, while both local and systemic symptoms were found in infected plants of the family Solanaceae (Table 3). Local infections were initially manifested as chlorotic spots, later becoming necrotic. Symptoms of systemic infections included: mottling, leaf chlorosis, leaf necrosis, and vein banding. Chlorotic ring spot symptoms were induced by isolate PV-0292 on N. benthamiana and by PV-0707 on N. occidentalis P1. Symptomatic and symptomless infections were confirmed by ELISA and electron microscopy.

Particle morphology. Flexuous rod-shaped particles indicating potyvirus infection were identified in leaf adsorption preparations subjected to electron microscopic examinations. No other viruslike particles were found. This suggested that a single virus type might be the cause of the passion fruit infections in the samples

Table 2. Incidence and serological reactions of virus-like infections on passion fruit in 15 districts of Uganda

\begin{tabular}{|c|c|c|c|c|c|c|c|c|}
\hline \multirow[b]{2}{*}{ Region } & \multirow[b]{2}{*}{ District } & \multirow{2}{*}{$\begin{array}{l}\text { Infection rate } \\
\text { (\% incidence) }\end{array}$} & \multirow{2}{*}{$\begin{array}{l}\text { Mean \% } \\
\text { incidence }\end{array}$} & \multirow{2}{*}{$\begin{array}{c}\text { Samples } \\
\text { tested }\end{array}$} & \multicolumn{4}{|c|}{ Antibody or antisera reaction } \\
\hline & & & & & МАВ-P-3-3H8 & CABMV ${ }^{\mathbf{b}}$ & PFRSVb $^{b}$ & CABMV+PFRSV \\
\hline Northern & Apac & $0-30$ & 5 & 3 & 2 & 0 & 2 & 0 \\
\hline \multirow[t]{3}{*}{ Eastern } & Iganga & $2-5$ & 3 & 1 & 0 & 0 & 0 & 0 \\
\hline & Mbale & $0-5$ & 2 & 1 & 0 & 1 & 0 & 0 \\
\hline & Sironko & 0 & 0 & 3 & 0 & 1 & 0 & 0 \\
\hline \multirow[t]{8}{*}{ Central } & Wakiso & $0-55$ & 40 & 13 & 3 & 0 & 4 & 1 \\
\hline & $\mathrm{NaRL}^{\mathrm{c}}$ & 100 & 100 & 10 & 10 & 3 & 3 & 4 \\
\hline & Mukono & $0-100$ & 67 & 34 & 4 & 12 & 4 & 1 \\
\hline & Mpigi & $10-85$ & 38 & 18 & 8 & 8 & 1 & 1 \\
\hline & Masaka & $25-100$ & 61 & 42 & 16 & 9 & 0 & 0 \\
\hline & Mubende & $5-50$ & 22 & 7 & 1 & 2 & 1 & 0 \\
\hline & Luwero & $45-50$ & 48 & 1 & 1 & 0 & 1 & 0 \\
\hline & Nakasongola & $5-20$ & 13 & 4 & 0 & 0 & 0 & 0 \\
\hline \multirow[t]{4}{*}{ Western } & Bushenyi & $5-75$ & 33 & 3 & 2 & 0 & 2 & 1 \\
\hline & Kabarole & $0-5$ & 2 & 1 & 1 & 0 & 0 & 0 \\
\hline & Kasese & $5-80$ & 21 & 9 & 5 & 0 & 5 & 0 \\
\hline & Mbarara & $5-90$ & 56 & 14 & 9 & 0 & 13 & 2 \\
\hline Totals & & & & 164 & 62 & 36 & 36 & 10 \\
\hline
\end{tabular}

${ }^{a}$ Infection rate is the percentage of symptomatic plants.

b CABMV, Cowpea aphid-borne mosaic virus and PFRSV, Passion fruit ringspot virus.

c Samples from the National Germplasm collection at the National Agricultural Research Laboratories. 
collected in Uganda. In ISEM, virus-like particles were strongly decorated with a polyclonal antiserum against PFRSV (Fig. 2). For PV-0707 and UGM-58, a modal length of $780 \mathrm{~nm}$ was measured for the flexuous particles, which falls within the range 650 to 900 $\mathrm{nm}$, typical for members of the genus Potyvirus (11).

Coat protein analysis. Nucleotide sequences were generated from the 3 -terminal regions (1,718 to 1,720 nucleotides) of eight isolates (deposited in GenBank, under accession numbers FJ896000-FJ896003 and FR694180-FR694183). The sequences contained a single open reading frame of 566 aa, encoding part of the $\mathrm{NIb}$ and the entire $\mathrm{CP}$ followed by a noncoding region of 238 to 239 nucleotides and a poly(A) tail. The $\mathrm{CP}$ cistron was predicted from aligning the polyprotein with that of other potyviruses. The proteolytic cleavage site Q/S in the context SVLSQ $\downarrow S$ resulted in a $\mathrm{CP}$ of approximately 275 aa with a $\mathrm{M}_{\mathrm{r}}$ of $31.2 \mathrm{kD}$.

BLAST analysis revealed sequence similarities with genomes of other potyviruses, including those known to infect Passiflora species. A phylogenetic analysis of CP sequences from the Ugandan isolates with $\mathrm{CP}$ sequences of potyviruses from passion fruit and

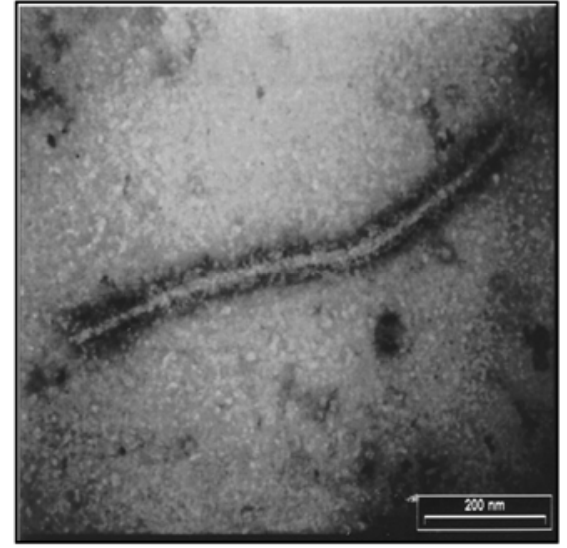

Fig. 2. Typical viral particle in passion fruit species from Uganda decorated with Passion fruit ringspot virus polyclonal antibodies as observed under electron micrographs.

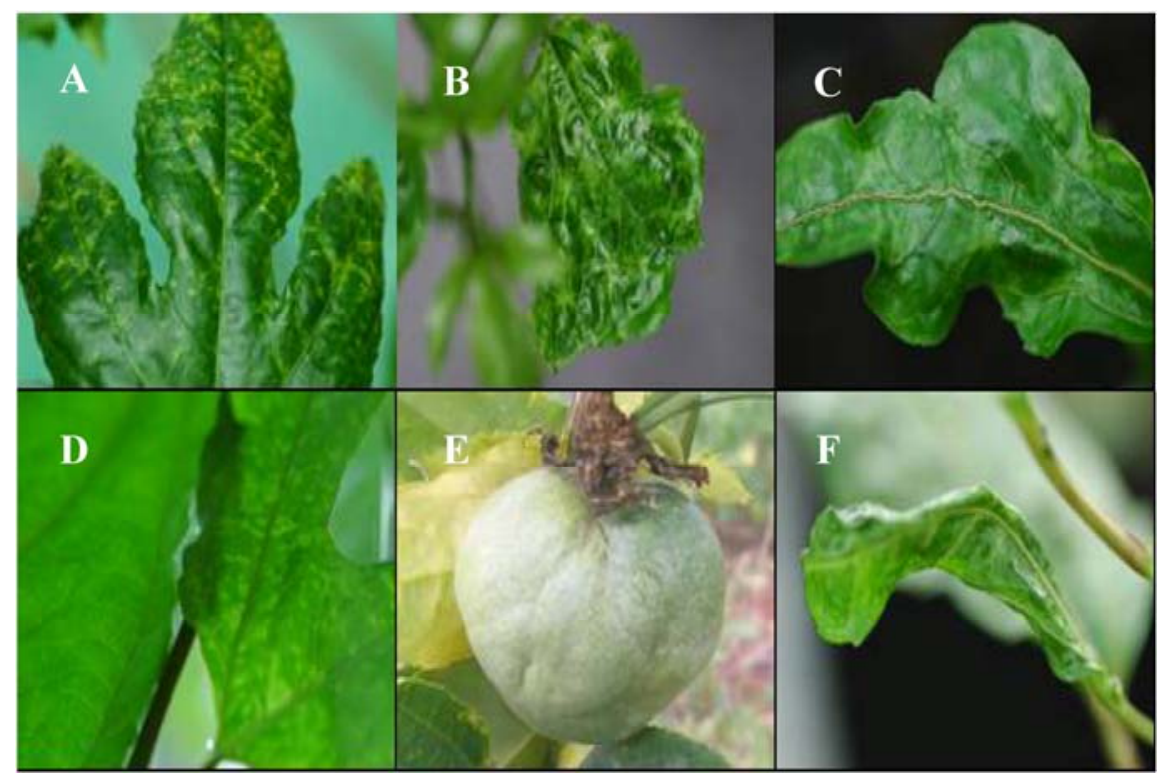

Fig. 1. Typical viral disease symptoms observed on passion fruit species in Uganda. A, Chlorotic spots; B, malformation, crinkle, and mosaic; C, malformation and mosaic; D, mottle; $\mathbf{E}$, fruit woodiness and malformation; and $\mathbf{F}$, leaf roll and mosaic.

Table 3. Host range and reactions of four passion fruit infecting virus isolates from Uganda

\begin{tabular}{|c|c|c|c|c|c|c|c|c|}
\hline \multirow[b]{3}{*}{ Plant family, species } & \multicolumn{8}{|c|}{ Isolates, types of infection ${ }^{a}$} \\
\hline & \multicolumn{2}{|c|}{ PV-0292 ${ }^{b}$} & \multicolumn{2}{|c|}{ PV-0707c } & \multicolumn{2}{|c|}{ UGM-19a ${ }^{c}$} & \multicolumn{2}{|c|}{ UGM-58c } \\
\hline & Local & Systemic & Local & Systemic & Local & Systemic & Local & Systemic \\
\hline \multicolumn{9}{|l|}{ Solanaceae } \\
\hline Nicotiana benthamiana & NI & $\mathrm{Vb}, \mathrm{M}, \mathrm{Rs}$ & NI & 1C, M, Mo & NI & NI & NI & Mo \\
\hline N. clevelandii & CS & 1C, Mo & NI & $1 \mathrm{C}, \mathrm{Mo}$ & $\mathrm{dCS}$ & NI & NI & NI \\
\hline$N$. hesperes & $1 \mathrm{CS}$ & CS & $\mathrm{CS}, \mathrm{lN}$ & CS & $\mathrm{CS}, \mathrm{lN}$ & 1C, Mo & NI & NI \\
\hline N. occidentalis subsp. obliqua & $\mathrm{CS}$ & NI & $\mathrm{dCS}$ & NI & NS & NI & NI & NI \\
\hline N. occidentalis $\mathrm{P} 1$ & $1 \mathrm{CS}, \mathrm{mN}$ & $\mathrm{CS}$ & Rs & Rs & Lat & NI & NI & NI \\
\hline Datura metel & NI & NI & NI & NI & NI & NI & NS & NI \\
\hline Solanum lycopersicum 'Rutgers' & NI & NI & NI & NI & NI & $\mathrm{CS}$ & NI & $\mathrm{CS}$ \\
\hline \multicolumn{9}{|l|}{ Chenopodiaceae } \\
\hline Chenopodium quinoa & $\mathrm{sCS}$ & NI & CS & $\mathrm{NI}$ & CS & NI & $\mathrm{CS}$ & NI \\
\hline C. murale & $\mathrm{sCS}$ & NI & NI & NI & Lat & NI & NS & NI \\
\hline C. foliosum & NL & NI & $\mathrm{CS}, \mathrm{lN}$ & NI & Lat & NI & NI & NI \\
\hline \multicolumn{9}{|l|}{ Leguminosae } \\
\hline Vigna unguiculata ‘Ife Brown’ & NI & $\mathrm{CS}$ & NI & NI & NI & NI & NI & NI \\
\hline
\end{tabular}

${ }^{a}$ Type of infection recorded with virus isolates tested: NI, no symptoms and negative in enzyme-linked immunosorbent assay; M, mottling; Mo, mosaic; 1C, leaf chlorosis; CS, chlorotic spots; 1CS, large chlorotic spots; sCS, small chlorotic spots; Lat, latent infection; 1N, leaf necrosis; mN, marginal necrosis; NS, necrotic spots; NL, necrotic lesions; Rs, ringspots; Vb, vein banding.

${ }^{\mathrm{b}}$ East Asian Passiflora virus (EAPV) isolate from Taiwan.

c Virus isolates from Uganda. 
other crops, available at GenBank, confirmed these similarities, but also provided further evidence for distinct sequence clades (Fig. 3). One clade had viruses related to CABMV (including isolates that were previously identified as Passion fruit woodiness virus from various hosts in Brazil). Other clades included the passion fruit potyviruses from Uganda, BCMV, PWV from Australia, and PaChV. Sequences of EAPV from Japan clustered further distant (Fig. 3).

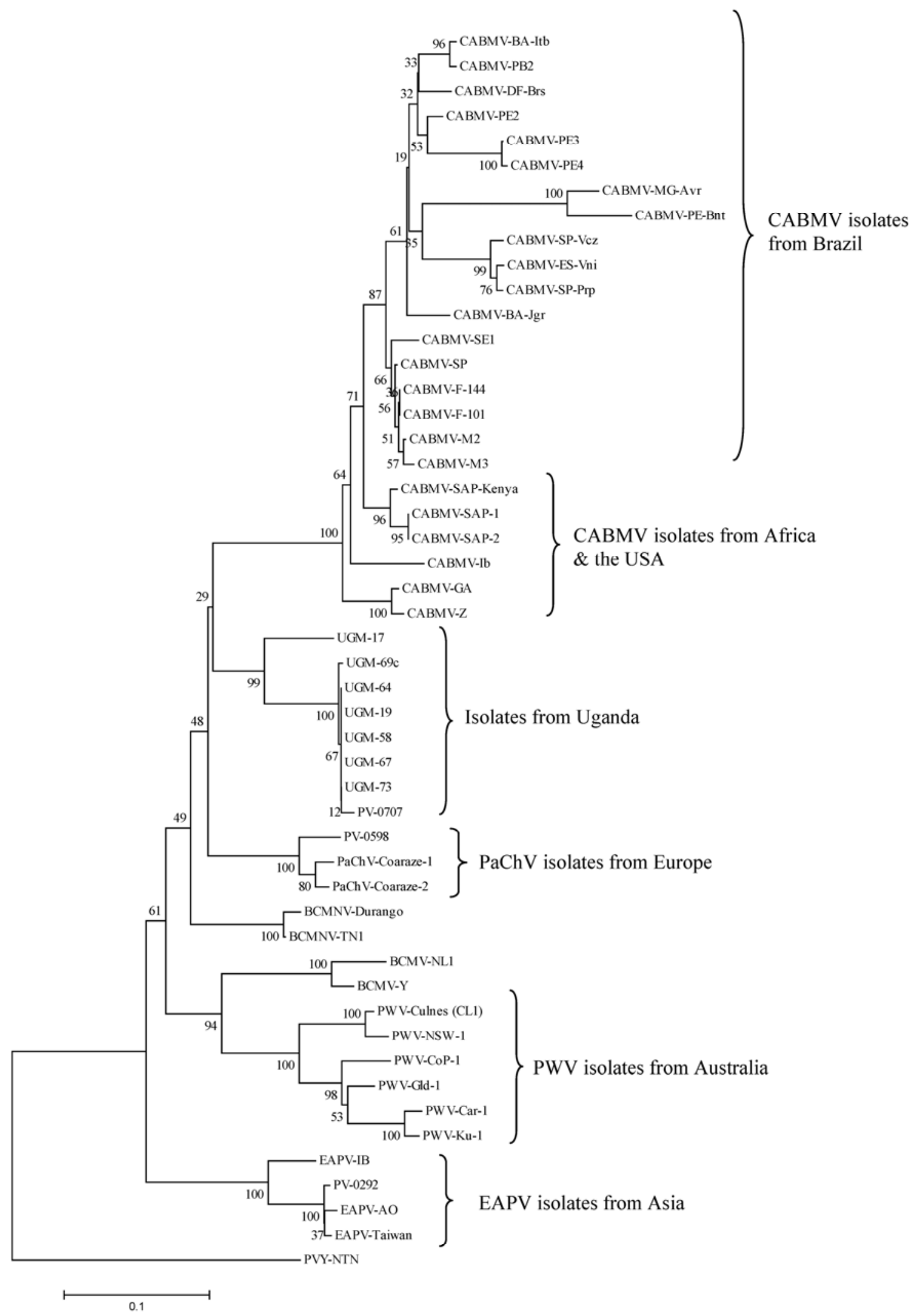

Fig. 3. Phylogenetic tree based on alignments of the predicted amino acid for the complete coat protein gene of eight potyvirus isolates from passion fruit in Uganda and isolates representing potyvirus species reported on passion fruit and/or other crops worldwide. Evolutionary history was inferred using the neighbor-joining algorithm of the MEGA program (version 4), with Poisson correction. Percentage of replicate trees in which the associated taxa clustered together in the bootstrap test (1,000 replicates) is shown next to the branches. Tree was rooted on the sequence of Potato virus $Y$. 
The passion fruit potyviruses from Uganda exhibited 72 to $79 \%$ amino acid identity with isolates of the Bean common mosaic necrosis virus (BCMNV) (with evolutionary divergence values between 0.17 and 0.19 ) and 73 to $76 \%$ identity with CABMV (with divergence values between 0.21 and 0.25 ) (Table 4). Lower $\mathrm{CP}$ aa sequence similarities were observed between the Ugandan passion fruit virus isolates and potyviruses found in passion fruit from other geographical areas, ranging from 44 to $46 \%$ (divergences between 0.17 and 0.19 ) with isolates of $\mathrm{PaChV}$; and 71 to $72 \%$ (divergences between 0.26 and 0.28 ) with PWV isolates.

The molecular diversity of Ugandan passion fruit virus isolates was very limited, and nucleotide variations were dispersed over the entire genome fragment analyzed. Only isolate UGM-17 showed a considerable difference in sequence, resulting in a $\mathrm{CP}$ with only $88 \%$ identical amino acid sequence (with a divergence of 0.1 ) to other Ugandan isolates, which were otherwise 99 to $100 \%$ identical (with divergences from 0 to 0.01). Most of the difference between UGM-17 and the other isolates was in a sequence of 18 aa (aa positions 20 to 38) just downstream of the DAG motif that was entirely unrelated to the aa conserved in the CP of all other isolates. This variation suggests the presence of two sequence groups within the Ugandan passion fruit virus, one comprising isolate UGM-17 and a possible second cluster represented by the sequences of isolates PV-0707, UGM-19a, UGM-58, UGM-64, UGM-67, UGM-69c, and UGM-73.

\section{Discussion}

In order to establish the incidence and distribution of viruses on wild and cultivated passion fruit species in Uganda, virus surveys were conducted in 15 major growing districts. Symptoms characteristic of PWD on fruits and conspicuous chlorotic mottle and distortion symptoms on leaves, which are indicative of virus infections, were found on passion fruit in all production areas in Uganda. Samples were positive for potyviruses using the genusspecific monoclonal antibody, and further investigation with virusspecific antisera indicated the possible presence of CABMV or PFRSV. No other viral species were detected in the 164 samples tested. In electron microscopic examinations, only flexuous filamentous particles typical of potyviruses were found, suggesting that only potyviruses were associated with symptomatic passion fruits in Uganda. However, no viruses were detected in about $50 \%$ of samples with conspicuous foliar viral symptoms. Serological assays, electron microscopy, double-stranded RNA profiling, and transmission to indicator plants did not demonstrate the presence of virus or confirm infectivity in these samples. While the presence of viruses in very low concentrations cannot be entirely excluded, it is likely that biotic factors such as plant responses to insect injury or abiotic factors such as incompatibility reactions of scions with rootstock in the early processes of graft joining caused the observed symptoms.

The potyvirus isolated from passion fruit in Uganda exhibited virions that were filamentous with a normal particle length of 780 $\mathrm{nm}$, well within the 680 to $900 \mathrm{~nm}$ range reported for potyviruses (6). Molecular analysis of the coat protein cistron, however, delineated the virus infecting passion fruit in Uganda as a potyvirus species distinct from other viruses associated with PWD or passion fruit chlorosis disease (including CABMV and $\mathrm{PaChV}$ ). The criteria set by the International Committee for Taxonomy of Viruses (20) and related taxonomic studies (1) suggest the benchmark for species demarcation in the family Potyviridae to be $80 \%$ identity for aa sequences over the complete $\mathrm{CP}$ gene (6). Using this criterion, the eight virus isolates from passion fruit in Uganda are all the same species. However, the Ugandan virus had less than $80 \%$ aa sequence identity with isolates of CABMV, and was even more distantly related to EAPV and PWV, species that cause similar disease symptoms on passion fruit elsewhere.

A host range study with isolates UGM-19a and UGM-58 further revealed distinct biological features of the Ugandan viruses. CABMV induced strain-characteristic symptoms on cowpea (7), a host which was not susceptible to infection with the passion fruit isolates (30). Whereas PFRSV caused latent infection in Chenopodium quinoa (14), the passion fruit virus isolates from Uganda caused chlorotic spots only. Isolate UGM-58 also produced mottling in Nicotiana benthamiana, which is not susceptible to EAPV (21). Thus, molecular, serological, and host range studies indicate the viral disease symptoms on passion fruit in Uganda are caused by a single virus with a limited molecular diversity among isolates. Only the heterogeneity observed in the N-terminus region of the

Table 4. Pairwise sequence comparison matrix for amino acid sequences of the complete coat protein gene of eight isolates of the "Ugandan Passiflora virus" and related potyvirus species ${ }^{\mathrm{a}}$

\begin{tabular}{|c|c|c|c|c|c|c|c|c|c|c|c|c|c|c|c|c|c|c|c|c|c|c|}
\hline Virus isolate & 1 & 2 & 3 & 4 & 5 & 6 & 7 & 8 & 9 & 10 & 11 & 12 & 13 & 14 & 15 & 16 & 17 & 18 & 19 & 20 & 21 & 22 \\
\hline BCMNV-Durango & & 0.01 & 19 & .25 & 0.22 & 0.22 & 0.20 & 0.20 & 0.24 & 0.17 & 0.19 & 0.46 & 0.22 & 0.21 & 0.18 & 0.18 & 0.18 & 0.18 & 0.18 & 0.18 & 0.19 & 0.19 \\
\hline BCMNV-TN1 & 90.8 & & 0.18 & 0.24 & 0.21 & 0.21 & 0.19 & 0.20 & 0.23 & 0.16 & 0.18 & 0.45 & 0.21 & 0.20 & 0.17 & 0.17 & 0.17 & 0.17 & 0.17 & 0.17 & 0.18 & 0.18 \\
\hline BCMV-Y & 68.2 & 73.1 & & 0.31 & 0.30 & 0.30 & 0.29 & 0.23 & 0.23 & 0.22 & 0.21 & 0.44 & 0.22 & 0.23 & 0.25 & 0.23 & 0.23 & 0.23 & 0.23 & 0.23 & 0.24 & 0.24 \\
\hline CABMV-BA-Itb & 67.6 & 73.8 & 64.4 & & 0.07 & 0.09 & 0.11 & 0.31 & 0.33 & 0.23 & 0.23 & 0.46 & 0.37 & 0.34 & 0.22 & 0.24 & 0.24 & 0.24 & 0.24 & 0.24 & 0.24 & 0.25 \\
\hline CABMV-M2 & 69.8 & 75.6 & 65.1 & 92.7 & & 0.06 & 0.09 & 0.30 & 0.31 & 0.22 & 0.24 & 0.46 & 0.36 & 0.31 & 0.22 & 0.22 & 0.22 & 0.22 & 0.22 & 0.22 & 0.22 & 0.23 \\
\hline CABMV-SAP-2 & 68.8 & 74.9 & 64.2 & 86.7 & 89.9 & & 0.09 & 0.29 & 0.30 & 0.22 & 0.23 & 0.46 & 0.34 & 0.31 & 0.22 & 0.21 & 0.21 & 0.21 & 0.21 & 0.21 & 0.21 & 0.21 \\
\hline CABMV-Z & 71.2 & 77.0 & 66.2 & 88.0 & 90.1 & 87.8 & & 0.27 & 0.29 & 0.22 & 0.21 & 0.46 & 0.34 & 0.30 & 0.23 & 0.23 & 0.23 & 0.23 & 0.23 & 0.23 & 0.23 & 0.24 \\
\hline EAPV-IB & 65.9 & 70.0 & 69.1 & 63.6 & 64.2 & 63.7 & 66.6 & & 0.07 & 0.24 & 0.24 & 0.40 & 0.27 & 0.26 & 0.24 & 0.24 & 0.24 & 0.24 & 0.24 & 0.24 & 0.24 & 0.24 \\
\hline PV $-0292^{b}$ & 63.9 & 69.0 & 68.8 & 62.8 & 63.5 & 63.7 & 65.2 & 84.6 & & 0.24 & 0.24 & 0.42 & 0.29 & 0.29 & 0.24 & 0.23 & 0.23 & 0.23 & 0.23 & 0.23 & 0.23 & 0.23 \\
\hline PaChV-Coaraze2 & 42.6 & 46.0 & 42.9 & 43.0 & 43.7 & 43.3 & 44.5 & 41.7 & 41.8 & & 0.05 & 0.44 & 0.27 & 0.27 & 0.17 & 0.17 & 0.17 & 0.17 & 0.17 & 0.17 & 0.18 & 0.18 \\
\hline PV-0598 & 40.7 & 44.0 & 41.8 & 41.7 & 41.5 & 41.6 & 42.7 & 40.0 & 40.6 & 89.4 & & 0.45 & 0.28 & 0.28 & 0.17 & 0.18 & 0.18 & 0.18 & 0.18 & 0.18 & 0.18 & 0.19 \\
\hline PVY-NTN & 55.3 & 57.5 & 55.5 & 56.1 & 57.1 & 55.8 & 56.4 & 56.5 & 56.4 & 34.1 & 32.7 & & 0.48 & 0.47 & 0.46 & 0.45 & 0.45 & 0.45 & 0.45 & 0.45 & 0.46 & 0.45 \\
\hline PWV-Car-1 & 68.4 & 73.9 & 74.2 & 63.2 & 64.2 & 64.4 & 65.0 & 67.3 & 66.6 & 41.6 & 40.1 & 55.1 & & 0.08 & 0.28 & 0.26 & 0.26 & 0.26 & 0.26 & 0.26 & 0.27 & 0.28 \\
\hline PWV-CoP-1 & 69.1 & 74.2 & 73.5 & 65.3 & 66.7 & 66.1 & 67.1 & 68.0 & 66.3 & 41.4 & 39.7 & 55.8 & 92.1 & & 0.26 & 0.26 & 0.26 & 0.26 & 0.26 & 0.26 & 0.27 & 0.28 \\
\hline UGM-17 ${ }^{\mathrm{d}}$ & 72.7 & 79.2 & 69.3 & 75.2 & 75.2 & 75.2 & 74.9 & 68.3 & 69.7 & 45.8 & 44.6 & 57.1 & 71.0 & 71.7 & & 0.10 & 0.10 & 0.10 & 0.10 & 0.10 & 0.10 & 0.11 \\
\hline UGM-19a $\mathrm{a}^{\mathrm{d}}$ & 72.3 & 78.5 & 70.0 & 73.8 & 75.6 & 75.2 & 74.1 & 69.0 & 70.1 & 45.6 & 44.0 & 57.5 & 71.7 & 71.7 & 88.0 & & 0.00 & 0.00 & 0.00 & 0.00 & 0.00 & 0.01 \\
\hline UGM- $58^{d}$ & 72.3 & 78.5 & 70.0 & 73.8 & 75.6 & 75.2 & 74.1 & 69.0 & 70.1 & 45.6 & 44.0 & 57.5 & 71.7 & 71.7 & 88.0 & 100.0 & & 0.00 & 0.00 & 0.00 & 0.00 & 0.01 \\
\hline UGM-73 & 72.3 & 78.5 & 70.0 & 73.8 & 75.6 & 75.2 & 74.1 & 69.0 & 70.1 & 45.6 & 44.0 & 57.5 & 71.7 & 71.7 & 88.0 & 100.0 & 100.0 & & 0.00 & 0.00 & 0.00 & 0.01 \\
\hline UGM-64 ${ }^{\mathrm{d}}$ & 72.3 & 78.5 & 70.0 & 73.8 & 75.6 & 75.2 & 74.1 & 69.0 & 70.1 & 45.6 & 44.0 & 57.5 & 71.7 & 71.7 & 88.0 & 100.0 & 100.0 & 100.0 & & 0.00 & 0.00 & 0.01 \\
\hline UGM- $67^{d}$ & 72.3 & 78.5 & 70.0 & 73.8 & 75.6 & 75.2 & 74.1 & 69.0 & 70.1 & 45.6 & 44.0 & 57.5 & 71.7 & 71.7 & 88.0 & 100.0 & 100.0 & 100.0 & 100.0 & & 0.00 & 0.01 \\
\hline UGM-69c ${ }^{d}$ & 72.0 & 78.1 & 69.6 & 73.8 & 75.6 & 75.2 & 74.1 & 68.7 & 69.7 & 45.4 & 43.8 & 57.1 & 71.4 & 71.4 & 87.6 & 99.6 & 99.6 & 99.6 & 99.6 & 99.6 & & 0.01 \\
\hline PV-0707d & 71.6 & 77.8 & 69.3 & 73.0 & 74.9 & 75.2 & 73.4 & 69.0 & 70.1 & 45.2 & 43.6 & 57.5 & 71.0 & 71.0 & 87.6 & 98.9 & 98.9 & 98.9 & 98.9 & 98.9 & 98.5 & \\
\hline
\end{tabular}

a Pair wise comparisons made with BioEdit version 7.0.4.1, derived using ClustalW multiple alignments with the following parameters: BLOSUM matrix, Gap open=10, Gap extension=0.1. Lower diagonal: Sequence identities, derived using CLC Protein Workbench version 5.4 and BioEdit version 7.0.4.1. Upper diagonal: Estimates of evolutionary divergence derived using the Poisson correction method in MEGA version 4.

${ }^{\mathrm{b}}$ EAPV isolate from Taiwan.

c PaChV isolate from Germany.

d Virus isolate from Ugandan passion fruit. 
isolate UGM-17 CP indicated variability within the "species". While the virus isolates PV-0707, UGM-19a, UGM-58, UGM-64, UGM-67, UGM-69c, and UGM-73 were almost identical; isolate UGM-17 was different. This kind of variation has been reported within the terminal regions of the $\mathrm{CP}$ gene of many other potyvirus species (6). These variations have been associated with erroneous replication mechanisms (23) and recombination (17) among plant RNA viruses, and present the foundation for population diversification that forms a "quasi-species" (33). However, with only a limited sample size available for the isolate UGM-17, further studies are necessary to substantiate the diversity among the Ugandan passion fruit viruses' sequences and biological traits.

The passion fruit virus in Uganda was isolated from passion fruit showing symptoms on leaves and striking woodiness symptoms on fruits and was genetically and biologically distinct from other potyviruses infecting passion fruit. The closest relationship was with BCMNV, a virus isolated from the leguminous plant Phaseolus vulgaris. We therefore suggest that the Ugandan passion fruit virus is a distinct virus species associated with passion fruit woodiness disease, for which we propose the name "Ugandan Passiflora virus".

\section{Acknowledgments}

Funding for this study was provided by Makerere University through the Innovations at Makerere Committee (funded by the Rockefeller Foundation and the World Bank) under Project I@Mak/2004/0044, the Integrated Pest Management Collaborative Research Support Program (IPM-CRSP) Award No. EPP-A00-04-00016-00) of the United States Agency for International Development, the International Foundation for Science (Research Grant C/3675-1), and through grants from the Norwegian agency for development cooperation (NORAD) and the Swedish International Development Agency (Sida-SAREC). Technical assistance was provided by the Plant Virology Department at the DSMZ in Braunschweig, Germany, the National Crops Resources Research Institute, the National Agricultural Research Laboratories (NaRL) of NARO, Uganda, and the Biotechnology Laboratory in the Department of Agricultural Production, Makerere University, Uganda. Our gratitude also goes to all the farmers who readily granted permission to inspect their passion fruit fields.

\section{Literature Cited}

1. Adams, M. J., Antoniw, J. F., and Fauquet, C. M. 2005. Molecular criteria for genus and species discrimination within the family Potyviridae. Arch. Virol. 150(3):459-479.

2. ADC/IDEA. 1999. 9th Semi-Annual progress report April-September 1999. The United States Agency for International Development (USAID), Kampala, Uganda. Contract \#623-0125-C-00-5040-00.

3. ADC/IDEA. 2002. 15th Semi-Annual progress report January-June 2002. The United States Agency for International Development (USAID), Kampala, Uganda. Contract \#623-C-00-95-0040-11.

4. Alfenas, P. F., Braz, A. S. K., Torres, L. B., Santana, E. N., Nascimento, A. V. S., Carvalho, M., Otoni, W. C., and Zerbini F. M. 2005. Transgenic passionfruit expressing RNA derived from Cowpea aphid-borne mosaic virus is resistant to passionfruit woodiness disease. Fitopatol. Bras. 30:33-38.

5. Baker, C. A., and Jones, L. 2007. A New Potyvirus found in Passiflora incence in Florida. Plant Dis. 91:227.

6. Berger, P. H., Adams, M. J., Brunt, A. A., Hammond, J., Hill, J. H., Jordan, R. L., Kashiwazalci, S., Rybicki, E., Spence, N., and Stenger, D. C. 2005. Family Potyviridae. Pages 819-841 in: Virus Taxonomy: Eighth Report of the International Committee on Taxonomy of Viruses. M. A. Mayo, J. Maniloff, U. Desselberger, L. A. Ball, and C. M. Fauquet, eds. Academic Press, Elsevier, London.

7. Bock, K. R. 1973. Peanut mottle virus in East Africa. Ann. Appl. Biol. 74:171-179.

8. Boyd, J., and Crucefix, D. 1997. Export marketing of passion fruit. The United States Agency for International Development (USAID), Kampala, Uganda. Contract \#623-0125-C-00-5040-00.

9. Brand, R. J., Burger, J. T., and Rybicki, E. P. 1993. Cloning, sequencing, and expression in Escherichia coli of the coat protein gene of a new Potyvirus infection South African Passiflora. Arch. Virol. 128:29-41.

10. Chen, J., Chen, J., and Adams, M. J. 2001. A universal PCR primer to detect members of the Potyviridae and its use to examine the taxonomic status of several members of the family. Arch. Virol. 146:757-766.

11. Chen, J., Chen, J., Chen, J., and Adams, M. J. 2001. Molecular characterization of an isolate of Dasheen mosaic virus from Zantedeschia aethiopica in China and comparisons in the genus Potyvirus. Arch. Virol. 146:1821-1829.

12. Colinet, D., Kummert, J., Duterme, O., and Lepoivre, P. 1995. Detection of plant viruses by PCR using group or virus specific primers (potyviruses, bymoviruses). EPPO Bull. 25:289-299.

13. De Silva, D. P. P., Jones, P., and Shaw, M. W. 2002. Identification and trans- mission of Piper yellow mottle virus and Cucumber mosaic virus infecting black pepper (Piper nigrum) in Sri Lanka. Plant Pathol. 51:537-545.

14. De Wijs, J. J. 1974. A virus causing ringspot of Passiflora edulis in the Ivory Coast. Ann. Appl. Biol. 77:33-40.

15. Defranq, M. 1989. Development of the Horticultural Industry UGA/87/003: Report of consultancy on plant protection in Horticulture. FAO-UN.

16. Dijkstra, T. 2001. Export Diversification in Uganda: Developments in NonTraditional Agricultural Exports. ASC Working Paper 47/2001. African Studies Centre, Leiden, the Netherlands.

17. Domingo, E., Baranowski, E., Ruiz-Jarabo, C. M., Martín-Hernández, A. M., Sáiz, J. C., and Escarmís, C. 1998. Quasispecies Structure and Persistence of RNA Viruses. Emerging Infectious Dis. 4:521-527.

18. Felsenstein, J. 1985. Phylogenies and the comparative method. Am. Nat. 125:1-15.

19. Hansen, A. J. 1990. Development of the Horticultural Industry UGA/87/003: Report of consultancy on tree fruit and vegetable virology. FAO-UN.

20. ICTV. 2005. ICTV approved Virus Orders, Families and Genera. In: Virus Taxonomy: Eighth Report of the International Committee on Taxonomy of Viruses. M. A. Mayo, J. Maniloff, U. Desselberger, L. A. Ball, and C. M. Fauquet, eds. Academic Press, Elsevier, London.

21. Iwai, H., Terahara, R., Yamashita, Y., Ueda, S., and Nakamura, M. 2006. Complete nucleotide sequence of the genomic RNA of an Amami-O-shima strain of East Asian Passiflora potyvirus. Arch. Virol. 151:1457-1460.

22. Iwai, H., Yamashita, Y., Nishi, N., and Nakamura, M. 2006. The potyvirus associated with the dappled fruit of Passiflora edulis in Kagoshima prefecture, Japan is the third strain of the proposed new species East Asian Passiflora virus (EAPV) phylogenetically distinguished from strains of Passion fruit woodiness virus. Arch. Virol. 151:811-818.

23. Malpica, J. M., Fraile, A., Moreno, I., Obies, C. I., Drake, J. W., and Garc1'a-Arenal, F. 2002. The rate and character of spontaneous mutation in an RNA virus. Genetics 162:1505-1511.

24. McKern, N. M., Strike, P. M., Barnett, O. W., Dijkstra, J., Shukla, D. D., and Ward, C. W. 1994. Cowpea aphid borne mosaic virus-Morocco and South African Passiflora virus are strains of the same potyvirus. Arch. Virol. 136:207-212.

25. Morton, J. 1987. Passionfruit. Pages 320-328 in: Fruits of Warm Climates. Julia F. Morton, Miami, FL.

26. Mwaka, A. 1990. The Passion Fruit. Kawanda Agricultural Research Institute, Uganda.

27. NARO. 1994. Draft report for NARO by task force on Horticulture research under the National Agricultural Research Organization-Uganda.

28. NARO. 1999. Annual report on research activities for the year 1996-97. National Agricultural Research Organization-Uganda. Pages 39-41.

29. NARO. 2003. Passion fruit research and production in Uganda. Final technical report on the KARI-IDEA Passion fruit Project IDEA-008. July 2003. National Agricultural Research Organization-Uganda.

30. Nascimento, A. V. S., Santana, E. N., Braz, A. S. K., Alfenas, P. F., PioRibeiro, G., Andrade, G. P., de Carvalho, M. G., and Zerbini, F. M. 2006 Cowpea aphid-borne mosaic virus (CABMV) is widespread in passionfruit in Brazil and causes passionfruit woodiness disease. Arch. Virol. 151:17971809.

31. Richter, J., Rabenstein, F., Proll, E., and Vetten, H. J. 1995. Use of crossreactive antibodies to detect members of the Potyviridae: J. Gen. Virol. 143:459-464.

32. Saitou, N., and Nei, M. 1987. The Neighbour-Joining method: A new method for reconstructing phylogenetic trees. Mol. Biol. Evol. 4:406-425.

33. Schneider, W. L., and Roossinck, M. J. 2001. Genetic diversity in RNA virus quasispecies is controlled by host-virus interactions. J. Virol. 75:65666571.

34. Shukla, D. D., Ward, C. W., Brunt, A. A., and Berger, P. H. 1998. Potyviridae: Description of Plant Viruses No. 366. CMI/AAB. URL: http://www.dpvweb.net/dpv/showadpv.php?dpvno=366\#relate (Accessed April 13, 2010).

35. Sseruwagi, P., Sserubombwe, W. S., Legg, J. P., Ndunguru, J., and Thresh, J. M. 2004. Methods of surveying the incidence and severity of cassava mosaic disease and whitefly vector populations on cassava in Africa: A review. Virus Res. 100:129-142.

36. Ssonko, R., Njue, E., Ssebuliba, J. M., and de Jager, A. 2005. Pro-Poor Horticulture in East Africa and South East Asia: The Horticultural Sector in Uganda. A publication of the International Society for Horticultural Science, Scripta Horticulturae Number 1, January 2005. Belgium.

37. Thompson, J. D., Higgins, D. G., and Gibson, T. J. 1994. CLUSTAL W: Improving the sensitivity of progressive multiple sequence alignment through sequence weighting, position specific gap penalties and weight matrix choice. Nucleic Acids Res. 22:4673-4680.

38. Wortmann, C. S., and Eledu, C. A. 1999. Uganda's agro-ecological zones: A guide for planners and policy makers. Centro Internationale de Agricultura Tropical (CIAT), Kampala, Uganda.

39. Yiga, L. K. 1992. Development of the Horticultural Industry in Uganda. UGA/87/003: Annual report for the year 1991. FAO-UNDP. 